\title{
Value of mortality data and necropsy records in monitoring morbidity in a population
}

\author{
G Károlyi, P Károlyi
}

\begin{abstract}
Study objective-The aim was to compare the value of four sources of data in assessing morbidity in a population: (1) data from a screening programme including follow up records, (2) death certifications by attending physicians, (3) death certifications by doctor-coroners, and (4) necropsy reports.

Design-The study was a cohort analysis of health and mortality in a sample of agricultural workers first examined in 196466 when they were aged 60 years or older. Follow up examinations enabled morbidity assessment to be made and ICD diagnostic categories to be compared with data available on persons in the cohort who had died.

Setting-Hajdúszoboszló, a small town in eastern Hungary.

Participants- 1412 persons (96.1\% of those aged $\geqslant 60$ years) were examined in 1964-6. Those still alive and available in 1989 were examined again. Necropsy records were available for 144 persons from the cohort in 1989 and were extensively reviewed in comparison with data available from other sources.
\end{abstract}

Measurements and main resultsComparison of causes of death established at necropsy showed marked differences from those registered by attending physicians and doctor-coroners, deviations ranging from $-91.6 \%$ to $+74.8 \% ; 19.4 \%$ of underlying causes of death occurred exclusively in the necropsy group. Major divergencies in diagnostic classification occurred in the three data sources, particularly for diseases of the circulatory system, where hypertensive renal disease, old myocardial infarction, acute cerebrovascular disease, and venous thrombosis were rarely documented by physicians/coroners. When necropsy data were used the number of diagnostic categories increased strikingly over the other sources of information. Necropsy records revealed quantitatively similar information on morbidity to follow up examination though there were qualitative differences, necropsy being less likely to document diagnoses of endocrine disorders, mental and neurological diseases, digestive disorders, and musculosketal disorders.

Conclusions-Necropsy records contain much valuable material not available from other sources, exceeding by ninefold the amount of information reported at present. A way should be found to make use of this large data pool.
An epidemiological study was performed by one of the authors between 1964 and 1966 in Hajdúszoboszló (a small town in the eastern part of Hungary). Data concerning the social status of persons aged 60 years or older, who had been employed in agriculture, were collected, and 1412 people $(96 \cdot 1 \%)$ were examined using an exhaustive screening programme. ${ }^{1}$ Mortality data (necropsy records if available) of persons who died from this group were carefully studied. In the summer of 1986 the living and available persons were examined in the same way as 20 years earlier.

The series of investigations made it possible to compare the usefulness of the four sources of epidemiological data: the screening programme, the follow up data, data from health authority registers and mortality data. ${ }^{2}$ We have found no comparative analysis of this kind in published reports so far.

About $75 \%$ of the total quantity of data recorded became known from the screening programme. The follow up revealed rather more than $20 \%$, the hospital and outpatient unit registers rather less than $20 \%$, of the diseases found in the given population. Mortality data contributed $1.5 \%$. However, a considerable amount of mortality data, particularly those that had been reported on the basis of necropsy, provided exclusive information.

It has been revealed from published reports that diagnoses other than the underlying cause of death are not generally given on death certificates. It has been reported ${ }^{3}$ that in the United States one certificate of death displays 1.81 diagnoses on average, and more than one diagnosis could be found in only $59.6 \%$ of the certificates. In another report from 1979 there were 2.35 diagnoses per case. ${ }^{4}$ Some further reports about the analysis of unrelated diseases in death certificates are available from the United States ${ }^{5-8}$ and what was then East Germany. ${ }^{9}$ We could find only one report about the epidemiological value of necropsy records in recent publications. ${ }^{10}$ Even the title of the article "The epidemiologic necropsy" by McFarlane and coworkers is remarkable. Therefore it seemed reasonable to examine the death certificates and necrospy records of our material in respect of obtainable data other than the underlying cause of death.

\section{Methods}

By the spring of 1989144 necropsy records had been collected. These documents were thoroughly examined and analysed, all data concerning any disease or loss of health was recorded, and this pool represents one data file in this work. 
Table I Average age in the three analysed groups.

\begin{tabular}{|c|c|c|c|}
\hline & \multicolumn{3}{|c|}{ Average age (years) in the groups based on } \\
\hline & $\begin{array}{l}\text { Necropsy } \\
\text { diagnosis }\end{array}$ & $\begin{array}{c}\text { Attending } \\
\text { physician's } \\
\text { diagnosis }\end{array}$ & $\begin{array}{l}\text { Doctor-coroner } \\
\text { diagnosis }\end{array}$ \\
\hline $\begin{array}{l}\text { Men } \\
\text { Women } \\
\text { Total }\end{array}$ & $\begin{array}{l}77 \cdot 7 \\
76 \cdot 7 \\
77 \cdot 2\end{array}$ & $\begin{array}{l}78 \cdot 2 \\
80 \cdot 8 \\
79 \cdot 4\end{array}$ & $\begin{array}{l}77 \cdot 0 \\
79 \cdot 6 \\
78 \cdot 2\end{array}$ \\
\hline
\end{tabular}

There are two other data files with which to make comparisons: death certificates which had been filled in by attending physicians and those completed by doctor-coroners. In this way we selected two control groups that corresponded to necropsy groups according to age and gender. The male/female ratio was $77 / 67$ in each group; deviation of mean ages can be seen in table $\mathrm{I}$. The analysed deaths occurred between 2 nd December, 1964, and 5th April, 1986.

The data obtained from the different sources were coded according to International classification of diseases, Revision IX, using three

Sources of reporting of underlying cause of death 1965-1987 (\% of death cases)

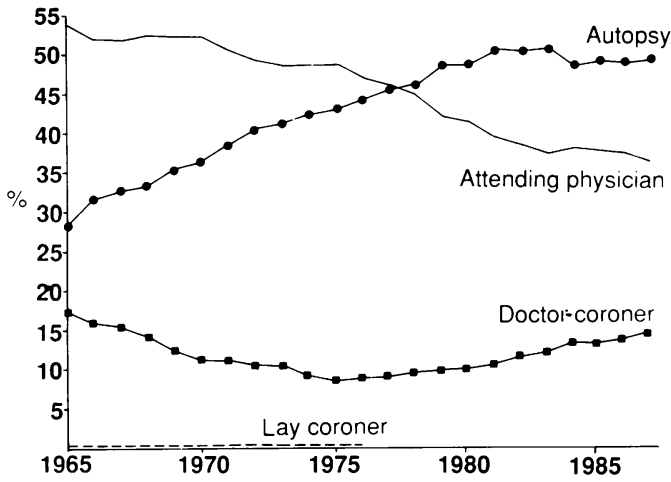

Table II Selected underlying causes of death of people aged 60 years or older on a nationwide level in 1965 and $1985^{\circ}$ and in the examined group in Hajduszoboszló 1965-1986.

\begin{tabular}{|c|c|c|c|c|c|c|}
\hline \multirow[b]{2}{*}{ ICD chapter } & \multirow{2}{*}{$\begin{array}{l}\text { National } \\
1965 \\
\text { (ICD VII) }\end{array}$} & \multicolumn{4}{|c|}{ In Hajdúszoboszló (ICD IX) based on } & \multirow{2}{*}{$\begin{array}{l}\text { National } \\
1985 \\
\text { (ICD IX) }\end{array}$} \\
\hline & & Necropsy & $\begin{array}{l}\text { Attending } \\
\text { physician }\end{array}$ & $\begin{array}{l}\text { Doctor- } \\
\text { coroner }\end{array}$ & Total & \\
\hline $\begin{array}{l}\text { Infectious and } \\
\text { parasitic diseases }\end{array}$ & & & & & & \\
\hline II Neoplasms & $\begin{array}{r}2 \cdot 2 \\
17 \cdot 4\end{array}$ & $\begin{array}{r}2 \cdot 1 \\
17 \cdot 4\end{array}$ & $\overline{15 \cdot 3}$ & $\overline{25 \cdot 7}$ & $\begin{array}{r}0 \cdot 7 \\
19 \cdot 4\end{array}$ & $\begin{array}{r}0 \cdot 6 \\
18 \cdot 8\end{array}$ \\
\hline \multicolumn{7}{|l|}{$\begin{array}{l}\text { VI Diseases of the } \\
\text { nervous system and } \\
\text { sense organs }\end{array}$} \\
\hline VII Diseases of the & 0.5 & 0.1 & - & - & $0 \cdot 2$ & $0 \cdot 4$ \\
\hline \multirow{2}{*}{$\begin{array}{l}\text { circulatory system } \\
\text { VIII Diseases of the } \\
\text { respiratory system }\end{array}$} & $61 \cdot 5$ & 46.5 & $61 \cdot 8$ & $56 \cdot 2$ & $54 \cdot 9$ & $61 \cdot 3$ \\
\hline & $5 \cdot 0$ & $11 \cdot 1$ & $19 \cdot 4$ & $15 \cdot 3$ & $15 \cdot 3$ & $5 \cdot 4$ \\
\hline $\begin{array}{l}\text { IX Diseases of the } \\
\text { digestive system } \\
\text { X Diseases of the }\end{array}$ & $3 \cdot 5$ & $8 \cdot 3$ & $0 \cdot 7$ & $1 \cdot 4$ & $3 \cdot 5$ & $4 \cdot 1$ \\
\hline \multirow{2}{*}{$\begin{array}{l}\text { genitourinary system } \\
\text { XVI Symptoms, signs } \\
\text { and ill-defined } \\
\text { conditions } \\
\text { XVII Injury and }\end{array}$} & 1.5 & $0 \cdot 7$ & $0 \cdot 7$ & - & $0 \cdot 5$ & $1 \cdot 5$ \\
\hline & $1 \cdot 8$ & - & $0 \cdot 7$ & - & $0 \cdot 2$ & $0 \cdot 1$ \\
\hline \multirow{2}{*}{$\begin{array}{l}\text { poisoning } \\
I I I+I V+V+X I I+ \\
\text { XIII + XIV }\end{array}$} & $3 \cdot 7$ & $13 \cdot 2$ & $1 \cdot 4$ & $1 \cdot 4$ & $5 \cdot 3$ & $5 \cdot 7$ \\
\hline & $2 \cdot 9$ & - & - & - & - & $2 \cdot 1$ \\
\hline Total & $100 \cdot 0$ & $100 \cdot 0$ & $100 \cdot 0$ & $100 \cdot 0$ & $100 \cdot 0$ & $100 \cdot 0$ \\
\hline
\end{tabular}

a See ref 11 .

b Cerebrovascular diseases were moved from chapter VI to chapter VII after 1965.

Table III Death cases resulting from old age (without mental disorders) after ill defined causes for 100000 people in four different countries ${ }^{\mathrm{a}}$.

\begin{tabular}{|c|c|c|c|c|c|c|}
\hline \multirow[b]{2}{*}{ Country } & \multicolumn{2}{|c|}{ 55-64 years } & \multicolumn{2}{|c|}{$65-74$ years } & \multicolumn{2}{|c|}{$75+$ years } \\
\hline & Men & Women & Men & Women & Men & Women \\
\hline $\begin{array}{l}\text { Belgium, } 1984 \\
\text { England and Wales, } 1984 \\
\text { Finland, } 1984 \\
\text { Hungary, } 1985\end{array}$ & $\begin{array}{r}59 \cdot 0 \\
1 \cdot 2 \\
5 \cdot 3 \\
0 \cdot 7\end{array}$ & $\begin{array}{r}21 \cdot 9 \\
0 \cdot 7 \\
3 \cdot 3 \\
-\end{array}$ & $\begin{array}{r}162 \cdot 8 \\
2 \cdot 0 \\
4 \cdot 9 \\
0 \cdot 6\end{array}$ & $\begin{array}{r}80 \cdot 7 \\
1 \cdot 6 \\
3 \cdot 1 \\
0 \cdot 4\end{array}$ & $\begin{array}{r}894 \cdot 6 \\
22 \cdot 4 \\
32 \cdot 1 \\
11 \cdot 1\end{array}$ & $\begin{array}{r}904 \cdot 7 \\
42 \cdot 4 \\
35 \cdot 7 \\
17 \cdot 2\end{array}$ \\
\hline
\end{tabular}

digit categories. The same document was used when the diagnoses of the death certificates were corrected.

\section{Results}

COMPARATIVE ANALYSIS OF UNDERLYING CAUSES OF DEATH

The registered numbers of deaths in Hungary in 1965 were 108119 , in 1975,131102 , and in 1985 , 147614 . The necropsy rate increased from $28 \cdot 4^{\circ}{ }_{0}$ to $49 \cdot 1^{\circ}$; the maximum rate in 1981 was $50.5^{\circ}$ o (fig 1). Meanwhile the proportion of underlying causes of death registered by attending physicians decreased from $54.0 \%$ to $36 \cdot 3^{\circ}$ o with only small oscillation. The role of doctor-coroners changed characteristically; their participation decreased from $17 \cdot 3^{\circ}{ }_{0}$ to $8 \cdot 4^{\circ}{ }_{0}$ by 1975 , and thereafter it gradually increased. Lay coroners ceased working in 1977. The Central Statistical Office has for a long time been reporting the distribution of underlying causes of death originating from three (previously four) different sources. In 1985, the most frequent underlying causes of death, Diseases of the circulatory system (VII), Neoplasms (II), and Injury and poisoning (XVII) were found in $78^{\circ}{ }_{0}$ of people having necropsy (A), and were registered by attending physicians in $86 \cdot 6^{\circ}{ }_{0}(\mathrm{~B})$, and by doctor-coroners in $88 \cdot 1^{\circ}{ }_{0}(\mathrm{C})$. There were statistically significant differences $(p<0.01)$ between (A) and (B), between (A) and (C), and between $(B)$ and $(C)$. These differences were the result of both objective and subjective causes.

Data from the whole country from both 1965 and 1985 are available only for the relationship between diagnosis and age. After making basic corrections in the 1965 data group (cerebrovascular diseases were shifted from chapter VI to chapter VII in the ICD), and comparing them with the data of 1985, no unexpected and/or important changes were obtained (table II). The proportion of infectious diseases decreased, whereas that of neoplasms, injury and poisoning increased. Particular attention should be paid to the fact that the proportion of Symptoms, signs and ill-defined conditions (XVI) decreased and is among the lowest rates in Europe (table III).

Comparing numbers of ICD chapters of diseases, the selected underlying causes of death could be categorised into eight chapters based on necropsy, seven chapters based on attending physicians' diagnostic information, and five chapters based on doctor-coroners' information. The picture is somewhat similar to this if we compare numbers of nosological classes (three digit categories). Forty-four such categories were used after necropsies, 30 by attending physicians and 32 by doctor-coroners.

It hardly needs to be proved that the most reliable of these three sources is necropsy. Comparing the two other groups to the necropsy group (table IV) remarkable differences can be found; $19 \cdot 4^{\circ}{ }_{0}$ of selected underlying causes of death occurred exclusively in the latter group.

Cardiac arrest or lethal cerebrovascular diseases might occur more frequently outside hospital. Apart from the diseases which undoubtedly existed, however, there could be other real underlying causes of death which the 
attending physicians or doctor-coroners were unaware of, with the result that they indicated some circulatory or respiratory disease as the underlying cause of death.

Diseases of the digestive system (IX) as well as injury and poisoning (XVII) occur more frequently in necropsy groups; this can be explained by the almost obligatory need for surgical intervention in the former group, and by the need for necropsy in suicide and accident cases ( 15 out of 432 cases were due to self hanging, one was due to poisoning with hydrochloric acid, and one to poisoning with barbiturate).

COMPARATIVE ANALYSIS OF FURTHER DIAGNOSES IN THE DEATH CERTIFICATE

From the point of view of the evaluation of morbidity statistics the majority of the diagnoses actually present have disappeared. We therefore

Table IV Proportional deviations in percentage of selected underlying causes of death from the necropsy group $(100 \%)$ in some ICD chapters.

\begin{tabular}{lll}
\hline & \multicolumn{2}{l}{$\begin{array}{l}\text { Selected underlying cause of death } \\
\text { established by }\end{array}$} \\
\cline { 2 - 3 } $\begin{array}{l}\text { Chapter } \\
\text { (ICD IX) }\end{array}$ & $\begin{array}{l}\text { Attending } \\
\text { physician }\end{array}$ & $\begin{array}{l}\text { Doctor- } \\
\text { coroner }\end{array}$ \\
\hline II Neoplasms & $-12 \cdot 1$ & $+47 \cdot 7$ \\
VII Diseases of the circulatory system & $+39 \cdot 2$ & +20.9 \\
VIII Diseases of the respiratory system & +74.8 & +37.8 \\
IX Diseases of the digestive system & -91.6 & -83.1 \\
XVII Injury and poisoning & -89.4 & -89.4 \\
\hline
\end{tabular}

Table $V$ Diagnoses occurring on death certificates of people aged 60 years or more (excluding selected underlying cause of death), Hajdúszoboszló 1965-1986.

\begin{tabular}{|c|c|c|c|c|c|}
\hline \multirow{2}{*}{\multicolumn{2}{|c|}{$\begin{array}{l}\text { Chapter } \\
(I C D I X)\end{array}$}} & \multicolumn{3}{|c|}{ Diagnosis established by } & \multirow[b]{2}{*}{$\begin{array}{l}\text { Total } \\
(n=432)\end{array}$} \\
\hline & & \multirow{2}{*}{$\frac{\text { Necropsy }}{5}$} & \multirow{2}{*}{$\begin{array}{c}\begin{array}{c}\text { Attending } \\
\text { physician }\end{array} \\
6\end{array}$} & \multirow{2}{*}{$\begin{array}{c}\begin{array}{l}\text { Doctor- } \\
\text { coroner }\end{array} \\
3\end{array}$} & \\
\hline & Infectious and parasitic diseases & & & & 14 \\
\hline & Neoplasms & 1 & - & - & 1 \\
\hline III dise & $\begin{array}{l}\text { Endocrine, nutritional and metabolic } \\
\text { eases, and immunity disorders }\end{array}$ & 3 & 4 & 1 & 8 \\
\hline org & $\begin{array}{l}\text { Diseases of the blood and blood-forming } \\
\text { ans }\end{array}$ & - & 2 & - & 2 \\
\hline 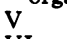 & Mental disorders & - & 3 & 9 & 12 \\
\hline $\begin{array}{l}\text { VI } \\
\text { sen }\end{array}$ & $\begin{array}{l}\text { Diseases of the nervous system and } \\
\text { se organs }\end{array}$ & & & 4 & 20 \\
\hline VII & $\begin{array}{l}\text { se organs } \\
\text { Diseases of the circulatory system }\end{array}$ & $\begin{array}{r}11 \\
147\end{array}$ & $\begin{array}{r}3 \\
162\end{array}$ & 204 & 513 \\
\hline VIII & Diseases of the respiratory system & 66 & 48 & 64 & 178 \\
\hline & Diseases of the digestive system & 35 & 5 & 12 & 52 \\
\hline $\begin{array}{ll}\mathrm{X}_{\mathrm{X}} \\
\mathrm{X} \mathrm{I}\end{array}$ & Diseases of the genitourinary system & 21 & 9 & 11 & 41 \\
\hline XI & $\begin{array}{l}\text { Diseases of the skin and subcutaneous } \\
\text { ue }\end{array}$ & - & 4 & 3 & 7 \\
\hline $\begin{array}{l}\text { XIII } \\
\text { and }\end{array}$ & $\begin{array}{l}\text { Diseases of the musculoskeletal system } \\
\text { connective tissue }\end{array}$ & - & 4 & 4 & 8 \\
\hline $\begin{array}{ll}X V I \\
\text { con }\end{array}$ & $\begin{array}{l}\text { Symptoms, signs and ill-defined } \\
\text { ditions }\end{array}$ & 9 & 19 & 11 & 38 \\
\hline XVII & Injury and poisoning & 4 & 2 & 2 & 8 \\
\hline Total & & 302 & 273 & 328 & 903 \\
\hline
\end{tabular}

Table VI The number of three digit categories (nosological classes) in the three groups examined.

\begin{tabular}{llll}
\hline & \multicolumn{2}{l}{$\begin{array}{l}\text { Number of three digit categories occurring on the death } \\
\text { certificates based on }\end{array}$} \\
\cline { 2 - 4 } $\begin{array}{l}\text { Type of } \\
\text { diagnosis }\end{array}$ & Necropsy & $\begin{array}{l}\text { Attending } \\
\text { physician }\end{array}$ & $\begin{array}{l}\text { Doctor- } \\
\text { coroner }\end{array}$ \\
\hline Selected underlying cause of death & 44 & 30 & 32 \\
Other & 62 & 49 & 48 \\
Total & 82 & 68 & 66 \\
\hline
\end{tabular}

Table VII The number and proportion of the diagnoses occurring on the death certificates in the three groups examined.

Number of diagnoses occurring on the death certificates based on

\begin{tabular}{llll}
$\begin{array}{l}\text { Type of } \\
\text { diagnosis }\end{array}$ & Necropsy & $\begin{array}{l}\text { Attending } \\
\text { physician }\end{array}$ & $\begin{array}{l}\text { Doctor- } \\
\text { coroner }\end{array}$ \\
\hline Cause of death & 144 & 144 & 144 \\
Other & 302 & 273 & 328 \\
Total & 446 & 417 & 472 \\
Other diagnosis/person & $2 \cdot 1$ & 1.9 & $2 \cdot 3$ \\
Total diagnosis/person & $3 \cdot 1$ & $2 \cdot 9$ & $3 \cdot 3$ \\
\hline
\end{tabular}

examined whether these data could be improved, and if so, how far this could improve our epidemiological knowledge.

We amassed in total 903 diagnoses in 432 cases from the three primary sources. It was unexpectedly found that most of the diagnoses were made by doctor-coroners, 328 diagnoses for 144 persons (table $\mathrm{V}$ ). The reason for this remains unclear. The persons whose death certificates had to be filled in were known the least by doctorcoroners, who could only receive information from the family or from available documents concerning previous medical history. Therefore, aiming at greater safety, they tend to provide more possible diagnoses on death certificates.

We also found important qualitative differences among the three possible sources. Three hundred and two diagnoses established by necropsy occurred in 10 ICD chapters and 62 three digit categories (tables V, VI). In the death certificates filled in by attending physicians there were 273 diagnoses, which could be divided into 13 chapters and 49 three digit categories. The death certificates of doctor-coroners contained 328 diagnoses in 12 chapters and 48 three digit categories.

Evidently, in some chapters and three digit categories there are significant differences among data from the three sources. Senile dementia (V 290) did not occur in the necropsy group, whereas it was found in 12 cases in the remaining two groups. The doctor who performed the necropsy was not aware of this (functional) disease or, if he was, the disease was not considered important enough to be indicated in the death certificate. Conversely, the diagnosis of cerebral atrophy (VI 331) was indicated in four cases, and brain oedema (348) in seven cases-only after necropsy.

The greatest divergence can be found in the group of diseases of the circulatory system (VII). The main cause for this has been mentioned above, and is supported by the following results: hypertensive renal disease (403), old myocardial infarction (412), acute cerebrovascular disease (436), and venous thrombosis (453) were frequently documented in necropsied cases in spite of the fact that doctors performing necropsy used $10 \%$ fewer diagnoses from this group than attending physicians and $30 \%$ fewer than doctorcoroners. But in the attending physician and doctor-coroner certifications, different types of atherosclerosis $(414,434,440)$, congestive heart failure (428), and myodegeneration of the heart (429) tended to predominate.

Diseases of the digestive system (IX) may prove lethal after surgery, leading to necropsy which is likely to be the reason for the excess found in this group.

In the group of the diseases of the genitourinary system $(\mathrm{X})$, findings relating to hyperplasia of prostate seemed surprising; this condition was found in only two necropsied cases as opposed to 13 such diagnoses from the other two sources.

The findings in the chapter Symptoms, signs and ill-defined conditions were as expected. It is remarkable, however, that while this group was cited as an underlying cause of death in only $0.2 \%$, it represents $4.3 \%$ in the whole material.

It can thus be stated that much information of great importance can be found in the death certificates besides underlying causes of death 
(table VII). The value of 2.9-3.3 diagnoses per case exceeds the all morbidity values of several investigations. ${ }^{13}$ The greatest number of diagnoses was found in the death certificates filled in by doctor-coroners but the most varied and probably the most reliable data could be found in the death certificates based on necropsy.

\section{COMPARATIVE ANALYSIS OF DIAGNOSES OF NECROPSY RECORDS}

Surveying necropsy records on the basis of which the death certificates were completed, we found 1295 diagnoses that could be coded according to the International classification of diseases. Among

Table VIII Distribution of diagnoses in necropsied cases according to their origin and ICD chapters $(n=144)$.

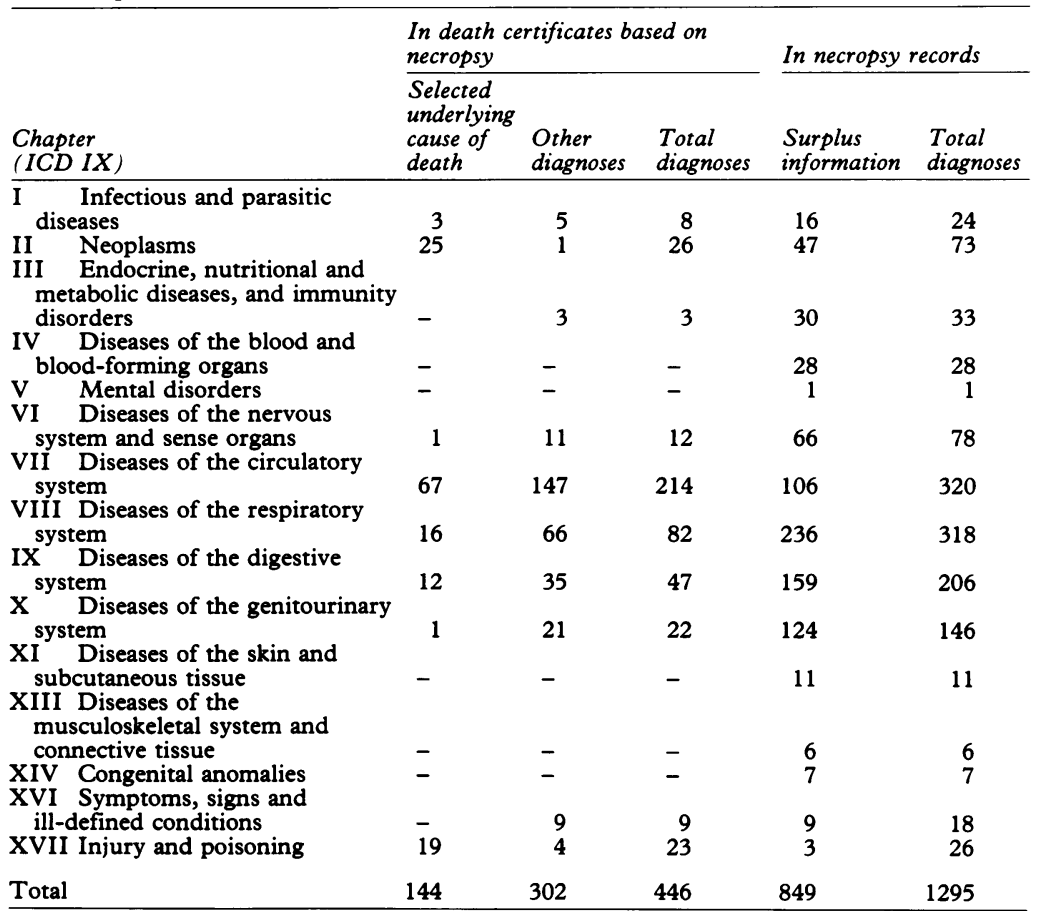

Table IX Distribution of three digit categories (nosological classes) in necropsied cases according to their origin and ICD chapters.

\begin{tabular}{|c|c|c|c|c|c|}
\hline \multirow[b]{2}{*}{$\begin{array}{l}\text { Chapter } \\
\text { (ICD IX) }\end{array}$} & \multicolumn{3}{|c|}{$\begin{array}{l}\text { In death certificates based on } \\
\text { necropsy records }\end{array}$} & \multicolumn{2}{|c|}{ In necropsy records } \\
\hline & $\begin{array}{l}\text { Selected } \\
\text { underlying } \\
\text { cause of } \\
\text { death }\end{array}$ & $\begin{array}{l}\text { Other } \\
\text { diagnoses }\end{array}$ & $\begin{array}{l}\text { Total } \\
\text { diagnoses }\end{array}$ & $\begin{array}{l}\text { Surplus } \\
\text { information }\end{array}$ & $\begin{array}{l}\text { Total } \\
\text { diagnoses }\end{array}$ \\
\hline $\begin{array}{ll}\text { Infectious and parasitic } \\
\end{array}$ & & & & & \\
\hline $\begin{array}{l}\text { diseases } \\
\text { II Neoplasms } \\
\text { III Endocrine, nutritional and }\end{array}$ & $\begin{array}{r}3 \\
10\end{array}$ & $\begin{array}{l}3 \\
1\end{array}$ & $\begin{array}{r}5 \\
10\end{array}$ & $\begin{array}{r}5 \\
14\end{array}$ & $\begin{array}{r}7 \\
24\end{array}$ \\
\hline $\begin{array}{l}\text { metabolic diseases, and immunity } \\
\text { disorders } \\
\text { IV Diseases of the blood and }\end{array}$ & - & 2 & 2 & 5 & 7 \\
\hline $\begin{array}{l}\text { blood-forming organs } \\
\text { V Mental disorders } \\
\text { VI Diseases of the nervous }\end{array}$ & $\begin{array}{l}- \\
-\end{array}$ & $\overline{-}$ & $\begin{array}{l}- \\
-\end{array}$ & $\begin{array}{l}2 \\
1\end{array}$ & $\begin{array}{l}2 \\
1\end{array}$ \\
\hline $\begin{array}{l}\text { system and sense organs } \\
\text { vII Diseases of the circulatory }\end{array}$ & 1 & 4 & 5 & 3 & 6 \\
\hline $\begin{array}{l}\text { system } \\
\text { VIII Diseases of the respiratory }\end{array}$ & 14 & 16 & 18 & 8 & 22 \\
\hline 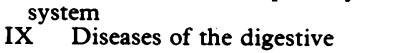 & 4 & 9 & 9 & 7 & 16 \\
\hline 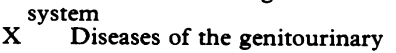 & 7 & 13 & 16 & 7 & 22 \\
\hline $\begin{array}{l}\text { system } \\
\text { XI Diseases of the skin and }\end{array}$ & 1 & 8 & 8 & 16 & 23 \\
\hline $\begin{array}{l}\text { subcutaneous tissue } \\
\text { XIII Diseases of the } \\
\text { musculoskeletal system and } \\
\text { connective tissue }\end{array}$ & - & - & - & 5 & 5 \\
\hline $\begin{array}{l}\text { connective tissue } \\
\text { XIV Congenital anomalies } \\
\text { XVI Symptoms, signs and }\end{array}$ & $\overline{-}$ & $\overline{-}$ & $\overline{-}$ & $\begin{array}{l}5 \\
5\end{array}$ & $\begin{array}{l}5 \\
5\end{array}$ \\
\hline $\begin{array}{l}\text { ill-defined conditions } \\
\text { XVII Injury and poisoning }\end{array}$ & - & $\begin{array}{l}2 \\
4\end{array}$ & $\begin{array}{l}2 \\
7\end{array}$ & $\begin{array}{r}4 \\
13\end{array}$ & $\begin{array}{r}5 \\
16\end{array}$ \\
\hline Total & 44 & 62 & 82 & 100 & 166 \\
\hline
\end{tabular}

these diagnoses were those that were also recorded in the death certificates, and in addition 849 diagnoses were noted as new information (table VIII). Diseases classifiable into a further five main groups appeared to be new in the records: diseases of blood and blood forming organs (IV), mental disorders $(\mathrm{V})$, diseases of the skin and subcutaneous tissue (XII), diseases of the musculoskeletal system and connective tissue (XIII), and congenital anomalies (XIV). (In the screening programme in 1964-1966 these diseases were diagnosed with a frequency of $2 \cdot 1^{\circ}{ }_{0}$.) Consequently the number of three digit categories increases remarkably. In contrast to the 44 different diagnoses of selected underlying causes of death or the 82 diagnoses on the death certificates, 166 different diagnoses categorisable into three digit categories could be found in the necropsy records (table IX).

The number of diagnoses from necropsy records in relation to those on the death certificates increased threefold and the number of three digit categories increased twofold. These differences became even more evident after relating the data to one dead person who had been necropsied (table $\mathrm{X}$ ). In contrast to the one officially completed and published diagnosis (underlying cause of deaths), nine diagnoses were found in the necropsy records. Additional information can be found in each ICD chapter in absolute values in groups VIII and IX, and relatively in group III (ninefold increase), in group X (sixfold increase), and in group VI (fivefold increase). Moreover, the majority of this additional information is likely to have been undiscovered without necropsy. The number of cases of pulmonary tuberculosis (011), different benign (not exclusively) neoplasms, cerebral degenerations and other conditions of the brain $(331,348)$, old myocardial infarction (412), acute pulmonary heart disease (415), different acute and chronic pulmonary diseases, chronic liver diseases and cirrhosis (571), and diseases of kidney and ureter (593) all increased.

It must be noted that there are qualitative and quantitative differences among single necropsy records, so the subjectivity of the doctors performing the necropsy can influence the content and the volume of this document. The doctors usually work following their own scheme and never deviate from it. These schemes vary depending on the person and the institution. This makes it more difficult to compare necropsy records from different places. Additional factors influencing the analysis are the doctors' knowledge, interest, and performance on a particular day. So far as our study is concerned, the most valuable records are given in those certificates which bring to light an unexpected underlying cause of death or in which an unclear cause of death was explored (eg, cases of sudden death). However, those records that served only as confirmation of a well known underlying cause of death (eg, self hanging) do not contain much information of relevance to our study.

COMPARISON OF VALUES FROM DIFFERENT SOURCES The most surprising results are derived from comparing the values from different sources. Working out the underlying causes of death 
provides a relatively small, monotonous mass of data. Elaboration of each diagnosis on the death certificates gives more useful results, exceeding those obtained from the data originating from official medical service records, and practically matching the follow up results. Concerning neoplasms (II), diseases of the circulatory system (VII), and diseases of the respiratory system (VIII), its level of effectiveness reaches the level of the screening programme. It proved to be ineffective, however, in ICD chapters III, VI, IX, XII, XIII compared to the three examinations performed in the living population.

The quantity of necropsy records exceeds (in some instances considerably) the amount of information coming from all other sources in ICD chapters I-IV, VII-X, XIV, and XVII. It has been shown by comparative analysis that in the groups of mental disorders $(\mathrm{V})$, diseases of organs

Table $X$ Number of diagnoses calculated for one necropsied person according to their origin and ICD chapters.

\begin{tabular}{|c|c|c|c|c|c|}
\hline \multirow[b]{2}{*}{$\begin{array}{l}\text { Chapter } \\
\text { (ICD IX) }\end{array}$} & \multicolumn{3}{|c|}{$\begin{array}{l}\text { In death certificates based on } \\
\text { necropsy records }\end{array}$} & \multicolumn{2}{|c|}{ In necropsy records } \\
\hline & $\begin{array}{l}\text { Selected } \\
\text { underlying } \\
\text { cause of } \\
\text { death }\end{array}$ & $\begin{array}{l}\text { Other } \\
\text { diagnoses }\end{array}$ & $\begin{array}{l}\text { Total } \\
\text { diagnoses }\end{array}$ & $\begin{array}{l}\text { Surplus } \\
\text { information }\end{array}$ & $\begin{array}{l}\text { Total } \\
\text { diagnoses }\end{array}$ \\
\hline $\begin{array}{l}\text { I Infectious and parasitic } \\
\text { diseases } \\
\text { II Neoplasms }\end{array}$ & $\begin{array}{l}0.021 \\
0.174\end{array}$ & $\begin{array}{l}0.035 \\
0.007\end{array}$ & $\begin{array}{l}0 \cdot 056 \\
0 \cdot 181\end{array}$ & $\begin{array}{l}0 \cdot 111 \\
0.326\end{array}$ & $\begin{array}{l}0 \cdot 167 \\
0.507\end{array}$ \\
\hline $\begin{array}{l}\text { III Endocrine, nutritional and } \\
\text { metabolic diseases, and immunity } \\
\text { disorders }\end{array}$ & & & & & \\
\hline $\begin{array}{l}\text { disorders } \\
\text { IV Diseases of the blood and }\end{array}$ & - & 0.021 & 0.021 & 0.208 & 0.229 \\
\hline blood-forming organs & - & - & - & $0 \cdot 194$ & $0 \cdot 194$ \\
\hline $\begin{array}{ll}\text { V } & \text { Mental disorders } \\
\text { VI } & \text { Diseases of the nervous }\end{array}$ & - & - & - & 0.007 & 0.007 \\
\hline system and sense organs & 0.007 & 0.076 & 0.083 & 0.459 & $0 \cdot 542$ \\
\hline $\begin{array}{l}\text { system } \\
\text { VIII Diseases of the resniratory }\end{array}$ & 0.465 & $1 \cdot 021$ & $1 \cdot 486$ & 0.736 & $2 \cdot 222$ \\
\hline system & $0 \cdot 111$ & 0.459 & 0.570 & 1.639 & $2 \cdot 209$ \\
\hline $\begin{array}{l}\text { IX Diseases of the digestive } \\
\text { system }\end{array}$ & $0 \cdot 083$ & $0 \cdot 243$ & 0.326 & $1 \cdot 104$ & $1 \cdot 430$ \\
\hline $\begin{array}{l}\text { system } \\
\text { XI Diseases of the skin and }\end{array}$ & 0.007 & $0 \cdot 146$ & $0 \cdot 153$ & $0 \cdot 861$ & $1 \cdot 014$ \\
\hline $\begin{array}{l}\text { subcutaneous tissue } \\
\text { XIII Diseases of the }\end{array}$ & - & - & - & 0.076 & $0 \cdot 076$ \\
\hline $\begin{array}{l}\text { musculoskeletal system and } \\
\text { connective tissue }\end{array}$ & - & - & - & 0.042 & 0.042 \\
\hline $\begin{array}{l}\text { ill-defined conditions } \\
\text { XVII Injury and poisoning }\end{array}$ & $\overline{0} \cdot 132$ & $\begin{array}{l}0 \cdot 063 \\
0.028\end{array}$ & $\begin{array}{l}0 \cdot 063 \\
0 \cdot 160\end{array}$ & $\begin{array}{l}0 \cdot 063 \\
0 \cdot 021\end{array}$ & $\begin{array}{l}0 \cdot 126 \\
0 \cdot 181\end{array}$ \\
\hline Total & 1.000 & 2.099 & 3.099 & $5 \cdot 896$ & 8.995 \\
\hline
\end{tabular}

of senses (VI), diseases of the skin and subcutaneous tissue (XII), and diseases of the musculoskeletal system and connective tissue (XIII) less information is obtainable in necropsy records than in the other sources of data. Different functional disorders (without any morphological signs), such as neurotic disorders and motility disorders of intestines, cannot be demonstrated by necropsy. Little attention is paid in necropsy to many diseases, eg, mycosis of the skin, conjunctivitis, haemorrhoids, deviation of the nasal septum, nasal polyps, rhinitis, diseases of the joints, and certain infectious diseases of the reproductive organs, so the records seldom reveal these diagnoses.

\section{Discussion}

Being aware of data concerning the state of health of the population is indispensable both for health authorities and for individual doctors. An overall picture can be obtained by using a combination of epidemiological, somatometric, demographic, and sociological methods. Epidemiological methods can be regarded as complete only if they include screening examination, follow up, analysis of documentation of different hospitals and outpatient units, and mortality documentation. Screening and follow up are extremely expensive, time consuming and labour consuming, so they can only occasionally be performed, being applied to representative population models. The examination of documentation is a secondary analysis, and its requirement for time and labour is much less than for the former method. Its reliability and accuracy should be increased to the maximum possible level and such analyses should routinely be applied for the whole population, or at least on representative samples, by using computation, and in this way the state of health of the population should be monitored continuously.

At present official analysis and reports of underlying causes of death from the mortality documentation is all that is done. It has been proved by our results that all diagnoses recorded on the death certificates exceed by three times, and those occurring in necropsy records by nine
Table XI The number of recorded diagnoses calculated for 100 persons aged 60 years or older according to the source of the information and ICD chapters, Hajdúszoboszló 1964-1985.

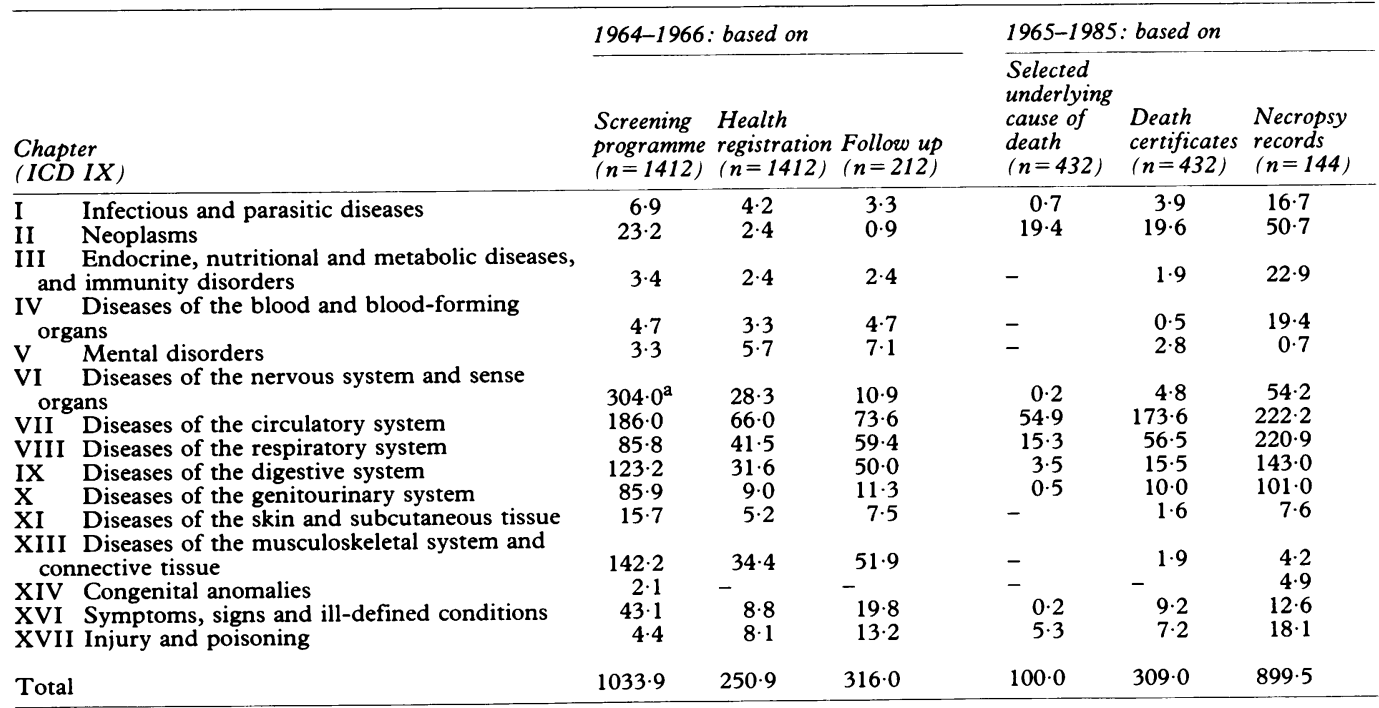

a Of these, diseases of the nervous system comprise only $0 \cdot 6^{\circ}{ }_{0}$ 
times, the amount of information reported at present. Significant differences can be found even in statistics of the Central Statistical Office depending on the source (attending physician, doctor-coroner, necropsy) of the main diagnosis. For this reason the source of the diagnosis must be stressed in the reported statistics. It seems reasonable to analyse each diagnosis occurring on the death certificates performed by attending physicians and doctor-coroners.

There are about 70000 necropsies performed in Hungary per year. Necropsy records are not used from an epidemiological point of view in spite of the fact that they contain a valuable and rich source of material not available from other sources. A way of utilising this large data pool should be sought. For example copies of necropsy records should be sent systematically to the attending physicians, who in this way could collect all the available information about the diseases of the dead person and compare the previous clinical findings with the necropsy diagnoses. Finally, a working group consisting of pathologists, epidemiologists, and demographers should be established.

This paper supported by Px Informatic Ltd, Hungary. The necropsies were performed by the Institute of Pathology, Institute of Legal Medicine of the Medical University, Debrecen (Hungary); in the Department of
Pathology, Hajdu County Hospital, Debrecen (Hungary); and in the Hajdu County Office of Police Medicine (Hungary). The authors wish to express their gratitude to these institutions.

1 Károlyi G. Population health care examinations in old agricultural people. PhD Thesis. Budapest: Hungarian Academy of Sciences, 197

2 Károlyi G. Sources of data and some methodical problems of general morbidity-epidemiological examinations. (In Hungarian.) Népegészségügy 1972; 53: 89-91.

3 Janssen TA. Importance of tabulating multiple causes of death. Am f Public Health 1940; 30: 871-9.

4 Israel RA, Rosenberg HM, Curtin LR. Analytical potentia for multiple cause-of-death data. Am $¥$ Epidemiol 1986; 124 161-79.

5 Dorn HF, Moriyama IM. Uses and significance of multiple cause tabulations for mortality statistics. Am $\mathcal{f}$ Public Health 1964; 54: 400-6.

6 Goodman RA, Manton KG, Nolan TF, Bregman DJ, Hinman AR. Mortality data analysis using a multiple-cause Hinman AR. Mortality data analysis

7 Chamblee RF, Evans MC. New dimensions in cause of death statistics. Am f Public Health 1982; 72: 1265-70.

8 White MC, Selvin S, Merrill DW. A study of multiple causes of death in California: 1955 and 1980. F Clin Epidemiol 1989; 42: 355-65.

9 Zahradka V. Signierpflichtige Begleitkrankheiten auf Totenscheinen. Z Arztl Fortbild (fena) 1989; 83: 735-6. 10 McFarlane MJ, Feinstein AR, Wells CK, Chan CK. The "epidemiologic necropsy". ҰAMA 1987; 258: 331-8.

11 Annual of Demography. Central Statistical Office (in Hungarian), 1965 and 1985.

12 Bericht über das Gesundheitswesen in Österreich im Jahre 1986. Vienna: Bundeskanzleramt-Österreichisches Statistisches Zentralamt, 1987: 239.

13 Balázsy K, Olaszy A. Methodology and comparative analysis of general morbidity examinations in European socialist of general morbidity examinations in European socialis

14 Károlyi G. Possibility of applying associative method based on the results of a screening programme of old agricultural on the results of a screening programme of old agricultural
population. (In Hungarian.) Orv Hetil 1972; 113: 1987-9. 